\title{
OSAKA MAP KEY
}

PLACES ASSOCIATED WITH SANO, HER

ACCOMPLICES, AND HER CLIENTS

1. Era-machi in Dōjima; where Sano first lived in Osaka

2. Naniwa Bridge; where Sano practiced water austerities

3. Shinchi Ura-machi in Dōjima; where Sano lived when she met Soyo, Kanzō, and Toki

4. Minami Kohata-machi in Tenma; where a number of Sano's clients lived Kawasaki; village where Sano met Yae and where she lived when she was arrested

Kitano; village where Sano had clients Shimo Sanba; village where Sano fled after returning from Nagasaki

PLACES ASSOCIATED WITH KINU, HER ACQUAINTANCES, AND HER CLIENTS

5. Tatsuta-machi in Tenma; where Kinu and Kahei lived when Kinu was arrested

6. Takama-chō; where Tōzō lived

7. Nōjin-machi in Tenma; where Kinu first lived in Osaka

8. Uoya-machi in Tenma; where Koto lived with her son, Jōsuke

9. Sunahara Yashiki in Tenma; later address of Koto and Jōsuke

\section{PLACES ASSOCIATED WITH UMON}

10. Kyōmachibori 4-chōme; where Umon initially lived in Osaka Sonezaki; village where Umon lived when he was arrested

\section{PLACES ASSOCIATED WITH HEIZŌ}

11. Matsuyama-machi; where Heizō lived when he was arrested
12. Owarizaka-chō; where Heizō lived when he met Gunki

13. Sakata-chō; where Heizō lived earlier

PLACES ASSOCIATED WITH KENZŌ

14. Funadaiku-machi in Dōjima; where Kenzō lived when he was arrested

15. Shinchi 1-chōme in Dōjima; where Kenzō lived as the adoptive son-in-law of Fujita Kyōan

PLACE ASSOCIATED WITH KINOSHIN

16. Tenma 7-chōme; where

Kinoshin lived when he was arrested

TEMPLES

17. Enkōji, Kita Miyahara; Sano's temple

18. Jōkōji, Shirokoura-machi; Umon's temple

19. Rentakuji, Tenma 1-chōme; Kinu's temple

2o. Kanzanji, Nishi Tera-machi in Tenma; Heizō's temple

21. Enshōji, Aburakake-machi; Kenzō's temple

OTHERS

Osaka Castle, headquarters of the Osaka governor

22. Osaka Eastern Magistracy

23. Osaka Western Magistracy

24. Matsuya-machi Jailhouse

25. Saitō-machi; residence of the author of The State of the Floating World

26. Tenma Tenjin Shrine

27. Tobita execution grounds 


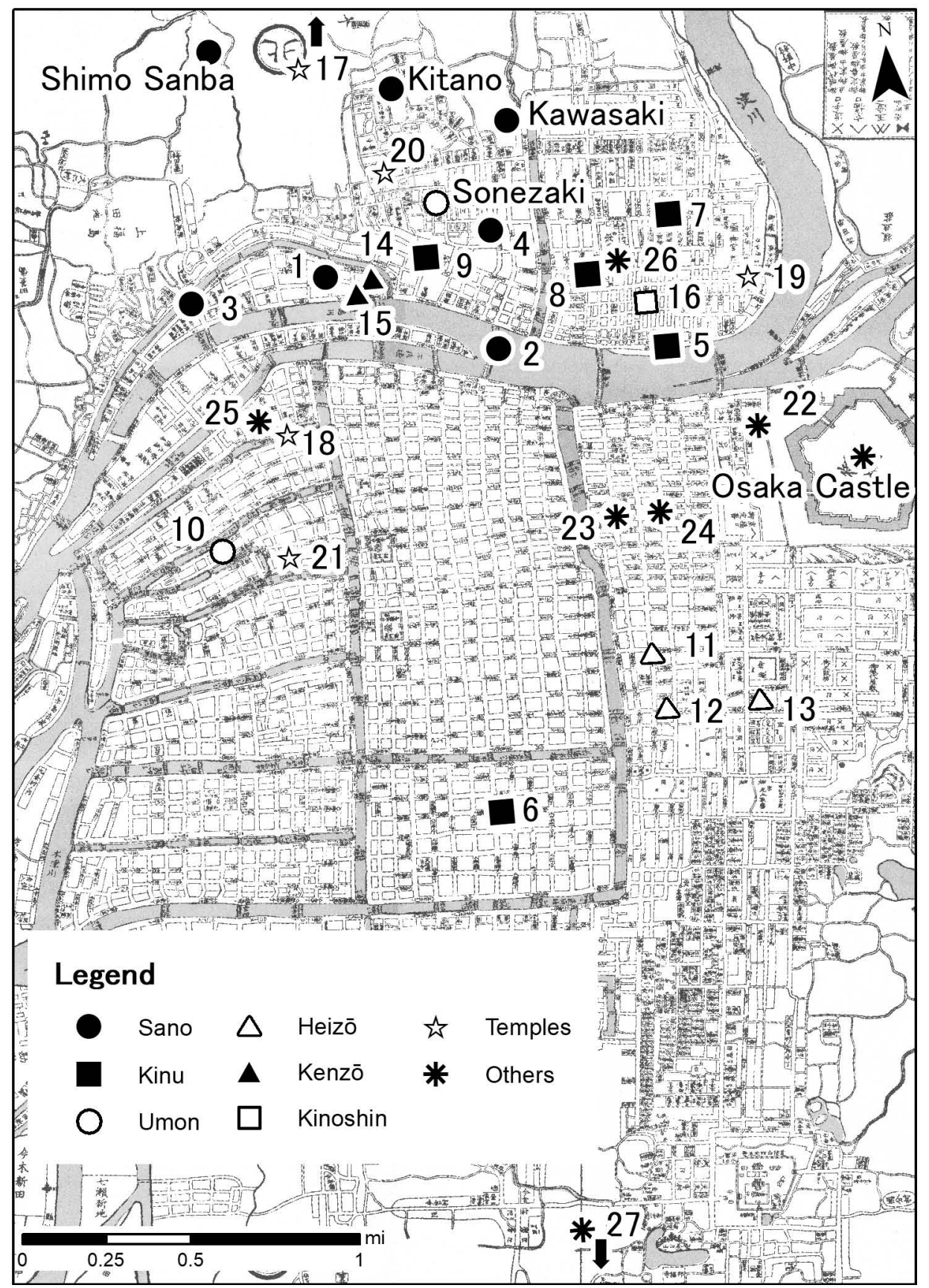

Figure 0.2 Map of Osaka. Satō Hirotaka. Based on Tenpō shinkai Sesshū Ōsaka zenzu (1837). International Research Center for Japanese Studies. 


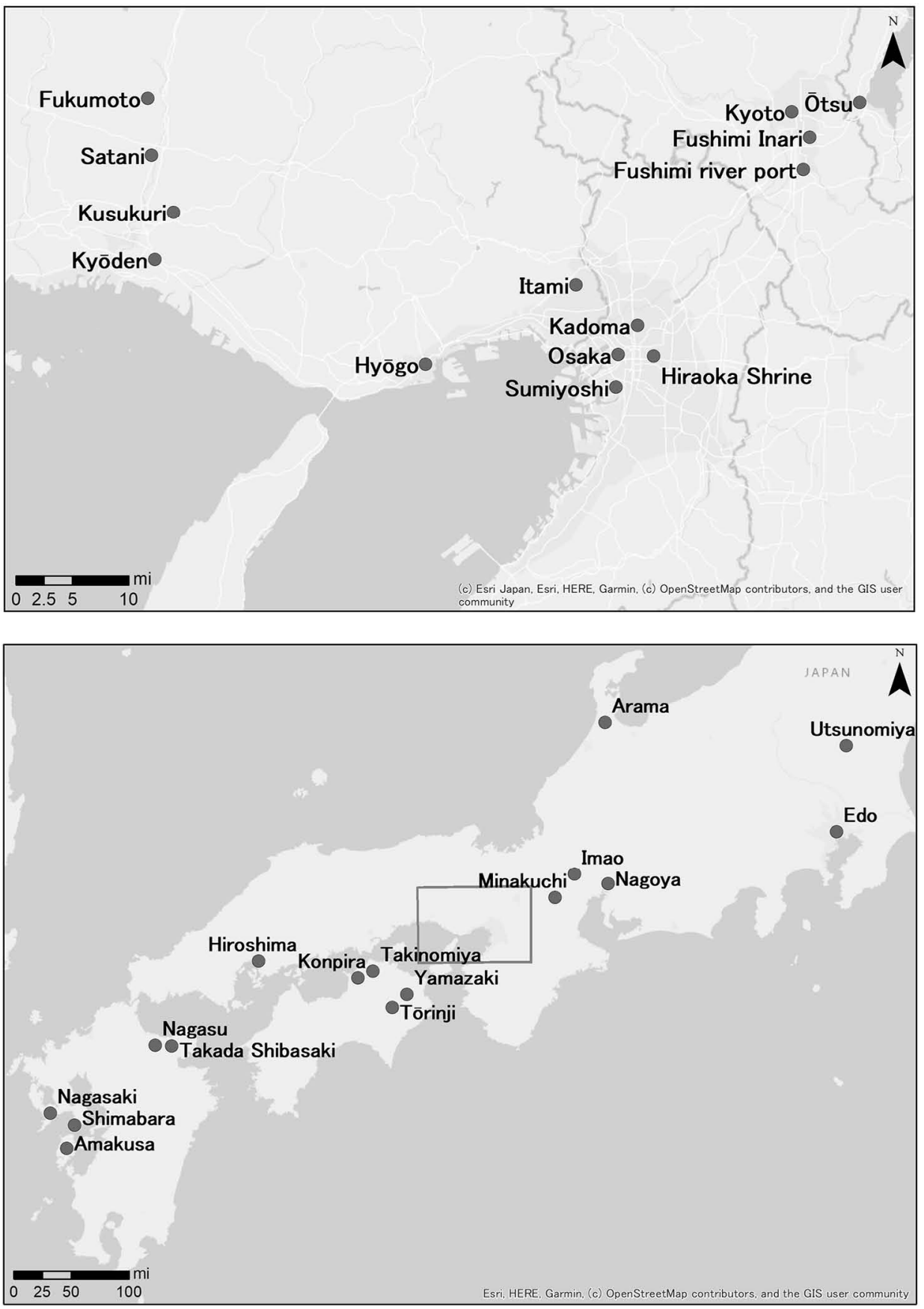

Figure o.3 Maps of the Kansai area and Japan (partial). Satō Hirotaka. 